\title{
FATE AND REMOVAL OF PHARMACEUTICALS AND ILLEGAL DRUGS PRESENT IN DRINKING WATER AND WASTEWATER
}

\author{
FARMACEUTYKI I NARKOTYKI ZANIECZYSZCZAJACE \\ WODY PITNE I ŚCIEKI. SPOSOBY ICH USUWANIA
}

\begin{abstract}
Rapid development of pharmaceutical industry, and thus widespread availability of different types of therapeutical and increased intake of pharmaceuticals, results in elevated concentrations of pharmaceuticals in municipal wastewater subjected to treatment in wastewater treatment plants. Pharmaceuticals present in raw wastewater discharged from hospitals, households, veterinary and health care clinics eventually end up in wastewater treatment plants. Commonly applied methods for treating wastewater do not allow complete removal of these contaminants. As a consequence, pharmaceuticals still present in treated wastewater are introduced to water environment. The most frequently identified pharmaceuticals in surface water belong to the following groups: non steroidal anti inflammatory drugs, beta-blockers, estrogens and lipid regulators. The most difficult is removal of diclofenac, clofibric acid and carbamazepine as these substances show low biodegradability. Diclofenac can be removed in the process of wastewater treatment by $40 \%$, carbamazepine by $10 \%$, and clofibric acid from 26 to $50 \%$. The presence of diclofenac sodium in the rivers in Poland was confirmed and the concentrations were following: $380 \mathrm{ng} / \mathrm{dm}^{3}$ (the Warta river), $470 \mathrm{ng} / \mathrm{dm}^{3}$ (the Odra river), $140 \mathrm{ng} / \mathrm{dm}^{3}$ (the Vistula river). Naproxene was found in the Warta river at the concentration of $100 \mathrm{ng} / \mathrm{dm}^{3}$. The presence of pharmaceuticals in surface water can be toxic to aqueous microorganisms and fish. Recent studies confirmed also the presence of pharmaceuticals in drinking water. This is considered as a problem especially in urban agglomerations such as Berlin or large cities in Spain and China. The studies showed that pharmaceuticals were also identified in the samples taken from the Polish rivers and drinking water. The presence of naproxene and diclofenac at the concentrations of 13 and $4 \mathrm{ng} / \mathrm{dm}^{3}$ was identified in drinking water sampled from water intakes in Poznan. Surface water and drinking water showed also the presence of illegal drugs.
\end{abstract}

Keywords: pharmaceuticals, illegal drugs, surface water, sewage, ecotoxicity, drinking water

\section{Introduction}

Pharmaceutical industry is one of the most rapidly growing in global economy. Annual sales of pharmaceuticals bring millions in revenue. According to the data from 2010 the annual profit from sales of pharmaceuticals brought 875 billions of US dollars globally [1]. Antibiotics that are used for treating infections both in people and animals are the most frequently prescribed pharmaceuticals (i.e. fluoroquinolones, sulfonamides). The quantity of antibiotics that are prescribed annually exceeds $12000 \mathrm{Mg}$ worldwide, including 65\%

\footnotetext{
${ }^{1}$ Institute of Environmental Engineering, Czestochowa University of Technology, ul. Brzeźnicka 60a, 42-200 Częstochowa, Poland, phone +48 601630207

*Corresponding author: szymonikanna1504@gmail.com
} 
(i.e. $8000 \mathrm{Mg}$ ) of antibiotics applied in health care, $29 \%$ (i.e. $3000 \mathrm{Mg}$ ) in veterinary and $6 \%$ as growth promoters in animal husbandry [2]. Pharmaceuticals used for treating hypertension (i.e. beta-blockers) such as atenolol, propranolol and metoprolol are the most frequently prescribed drugs among others in Canada. Sales of these pharmaceuticals were estimated at about $12 \mathrm{Mg}$ in 2007 (according to the IMS Health - an international company for market analysis of health care services and pharmaceuticals [3]). Beta-blockers are reported to be the most frequently prescribed drugs in Germany and the Unites States of America [4]. Also, non steroidal anti inflammatory drugs belong to the group of pharmaceuticals that are sold without prescription in large quantities. The data from the IMS Health indicate that diclofenac is the most frequently prescribed drug among non steroidal painkillers. The global intake of this drug in 2007 exceeded $877 \mathrm{Mg}$, and in 2008 it increased to $940 \mathrm{Mg}$ [5]. In Great Britain the annual sales of naproxene, paracetamol, acetylsalicylic acid and ibuprofen is estimated at $3000 \mathrm{Mg}$. The other group of the most widely prescribed pharmaceuticals sold in large quantities in Great Britain are antidepressants that inhibit selective serotonin reuptake (i.e. SSRI) including paroxetine, fluoxetine (Prozac) and citalopram. Fluoxetine is the most frequently prescribed antidepressant in France. The sales of these drugs in Great Britain in 2004 exceeded $5000 \mathrm{~kg}[6,7]$. The data from the IMS Health indicate that the largest quantities of pharmaceuticals sold in Poland belong to the over the counter drugs (OTC) and are used in pain relief, treatment of cold and flu symptoms. The most frequently prescribed drugs are for arterial hypertension (i.e. metoprolol, propranolol, atenolol). The sales of these drugs in the first quarter of 2013 were estimated at 674 million PLN [3].

Consumed pharmaceuticals are metabolized (i.e. biotransformation) which means that their molecules undergo chemical and structural changes. Biotransformation occurs mostly in the liver (about $2 / 3$ of a dose) but also in the blood, lungs and digestive system, and aims at conversion of a slowly released, nonpolar and lipophilic molecule of a drug into a hydrophilic and polar molecule. Metabolism of pharmaceuticals does not occur in $100 \%$. This means that metabolized forms as well as free forms of the drug are excreted with urine [8]. Pharmaceuticals that are past the expiration date are often flushed in toilets and discharged from households with wastewater. The highest loads of pharmaceuticals are detected in wastewater from hospitals and health care centers. Veterinary offices and animal husbandry contribute to the contamination of natural environment with pharmaceutical substances. Frequently applied pharmaceuticals in veterinary and animal husbandry are antibiotics that apart from treatment of microbial infections are added to animal feed as growth promoters. These drugs with the animal manure are applied for soil fertilization, and thus this can result in migration of the drugs to groundwater. Wastewater treatment does not completely remove pharmaceuticals. The pharmaceutical residues with treated wastewater (also with non treated wastewater) are introduced to surface water $[6,9]$.

The overall goal of this article is to present the current knowledge on contamination of surface and drinking water with pharmaceuticals introduced to the environment with treated wastewater.

\section{The most common pharmaceuticals in treated wastewater and potential methods for removal}

Table 1 presents the list of pharmaceuticals that are the most frequently identified in water environment and description of applications as medical substances. According to the 
available data pharmaceuticals that belong to the beta-blocker group, non steroidal anti inflammatory drugs, drugs affecting nervous system, hormones, lipid regulators and antibiotics are the most frequently identified pharmaceuticals in surface water. The presence of these medical substances can have negative effects on aqueous organisms [6].

Table 1

Characteristics of pharmaceuticals that are the most frequently identified in surface water

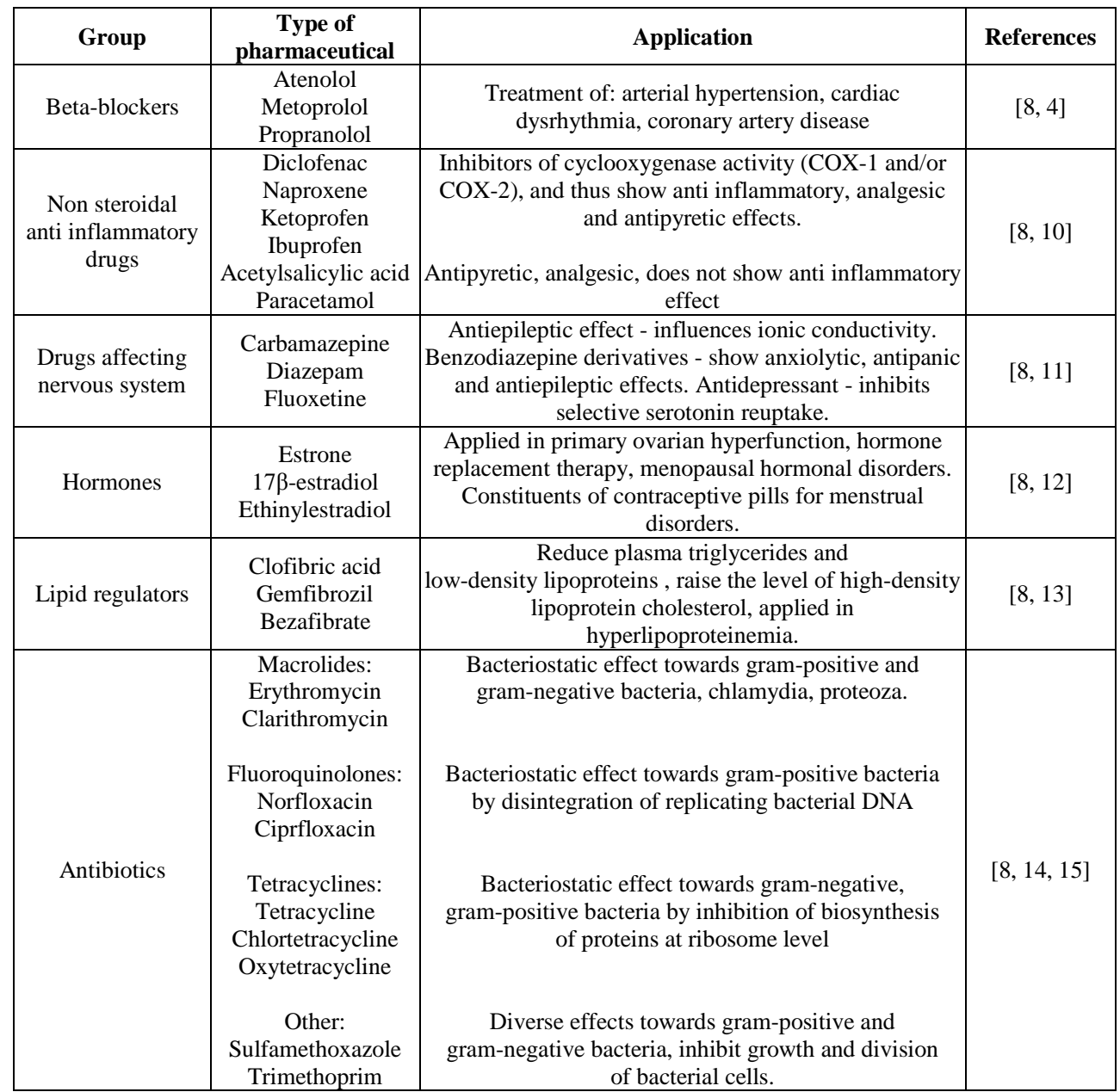

\section{Removal of pharmaceuticals from wastewater}

Most of wastewater treatment methods do not allow the total removal of microcontaminants resulted from contamination with pharmaceuticals. The removal rate of pharmaceuticals depends on physical and chemical properties of a given drug. Pharmaceuticals are removed through biodegradation, adsorption on activated sludge, flocculation, coagulation, photolysis, adsorption on activated carbon, ozonation or ozonation combined with $\mathrm{H}_{2} \mathrm{O}_{2}$. These methods allow the removal of pharmaceuticals from 
wastewater at different rate $[6,16]$. However, most of them are not applied in municipal wastewater treatment plants.

\section{Beta-blockers}

Beta-blockers cannot be completely removed during the treatment of wastewater. Atenolol can be removed up to $30 \%$ mostly through biotransformation. Insignificant quantities of this pharmaceutical are adsorbed on activated sludge. Metoprolol is removed at a very low rate through biotransformation (less than 10\%) and the concentration of propranolol (the most lipophilic beta-blocker) almost does not change during the treatment of wastewater [4, 17, 18]. Ozonation applied during wastewater treatment increases the removal of atenolol up to $86 \%$ and metoprolol up to $93 \%$, respectively [7].

Non steroidal anti inflammatory, analgesic and antipyretic drugs

\section{Diclofenac}

Diclofenac can be adsorbed on activated sludge up to $80 \%$. However, the average rate of adsorption ranges between 21 and 40\% [5]. Diclofenac undergoes biodegradation only partially (less than 25\%). This is due to low biodegradability caused by the presence of $\mathrm{Cl}$ atoms and $\mathrm{N}-\mathrm{H}$ group that inhibit the growth of bacteria in wastewater. Diclofenac can be also removed through photolysis $(25-75 \%)[19,20]$. The application of membrane filters allows the removal of diclofenac by about $58 \%$. Ozonation can allow obtaining the removal efficiency even up to $98 \%$. Combined ozonation with $\mathrm{H}_{2} \mathrm{O}_{2}$ allows sufficient removal of diclofenac $[7,21]$. The concentration of diclofenac in treated wastewater ranged from 140 to $1480 \mathrm{~g} / \mathrm{dm}^{3}$ (in the samples from $5 \mathrm{EU}$ countries) [22].

\section{Naproxene}

Naproxene is removed by $50-80 \%$ from wastewater due to adsorption on activated sludge [19]. Adsorption on activated carbons allows the removal of naproxene by $52 \%$, ozonation by about $90-99 \%$, and the combined ozonation with $\mathrm{H}_{2} \mathrm{O}_{2}$ by $89 \%$ [7]. Photolysis can remove naproxene by $99-100 \%$ [22]. Application of membrane bioreactors allows the removal of naproxene from wastewater by $86 \%$ [23].

Ibuprofen

Ibuprofen is one of the most efficiently removed pharmaceuticals. The removal rate of this pharmaceutical from wastewater is about $60-100 \%$. Sedimentation allows the removal of $12-45 \%$. However, the main mechanism behind this process is decomposition to hydroxyl and carbonyl groups, and the products of decomposition are removed through membrane filtration $[19,20]$. Ibuprofen is efficiently removed through adsorption on activated carbons (up to 99\%) and ozonation (up to 80\%) [7]. Photocatalysis is considered an efficient removal of ibuprofen $\left(\mathrm{TiO}_{2}\right.$ as a catalyst). At the $\mathrm{TiO}_{2}$ concentration of $1.0 \mathrm{~g} / \mathrm{dm}^{3}$ and 30 minute exposure to light ibuprofen underwent almost total decomposition [24].

Ketoprofen, paracetamol, acetylsalicylic acid

Ketoprofen can be removed through the processes of coagulation, flocculation and sedimentation in the range of $15-98 \%$. Adsorption on activated sludge allows the removal of ketoprofen in the range of $65-77 \%$ [7, 19]. However, the most efficient method for 
removal of ketoprofen is membrane filtration that eliminates $98 \%$ of this pharmaceutical [23].

Paracetamol is adsorbed on activated sludge in $99 \%$ whereas in $100 \%$ on membrane filters. It is also efficiently removed (i.e. above 90\%) through chlorination, adsorption on activated carbons and ozonation. Paracetamol is considered to be one of the most efficiently removed pharmaceuticals in the process of wastewater treatment [23]. Acetylsalicylic acid in removed through biodegradation in 80-98\% [19].

Antiepileptic, anticonvulsants, antidepressants

Carbamazepine

The presence of carbamazepine in the environment was first detected in 1978 in the United States of America and in 1985 in Great Britain [11]. Carbamazepine is a pharmaceutical that is not easily removed during the processes of wastewater treatment. According to the studies only 6-10\% of this pharmaceutical can be removed. Carbamazepine is susceptible to biodegradation. It was classified as "non removable" due to the fact that no biodegradation of carbamazepine at the concentration of $0.5 \mathrm{mg} / \mathrm{dm}^{3}$ in salt water was observed [5]. Chlorination also has no effect on the concentration of carbamazepine in wastewater. Adsorption on activated sludge combined with photolysis allows removal of carbamazepine in $29 \%$. The most efficient methods for the elimination of carbamazepine include ozonation (above 90\%), adsorption on activated carbons (up to $90 \%$ ), and ozonation combined with $\mathrm{H}_{2} \mathrm{O}_{2}(98-99 \%)$. Photolysis is less efficient for removal of carbamazepine from wastewater whereas membrane filters show very low removal rate (about 13\%) [7, 22].

\section{Diazepam and fluoxetine}

Diazepam undergoes biodegradation at a very low rate. According to the laboratory studies diazepam biodegraded by $70 \%$ after 84 days. Also, adsorption of diazepam on activated sludge is insignificant (about 2\%) [25]. Adsorption on activated carbons (up to $99 \%$ ) and ozonation (up to $81 \%$ ) are considered efficient methods for removal of contamination caused by diazepam [7].

Fluoxetine - a two ring pharmaceutical that belongs to the SSRI group of antidepressants (i.e. selective serotonin reuptake inhibitors) is removed through coagulation only by $15 \%$. Floxetine can be removed from wastewater through adsorption (by $92 \%$ ), ozonation (by 91\%) and ozonation combined with $\mathrm{H}_{2} \mathrm{O}_{2}$ (above 91\%) [7]. Fluoxetine is transported with treated wastewater to surface water, and there it can undergo sedimentation due to low solubility [26].

\section{Hormones}

Load of estrogens in wastewater depends on the number of women who are in the reproductive age, pregnant women, menopausal women (an organism of a pregnant woman produces 120 times more 17 $\beta$-estradiol in comparison to a non pregnant woman), and women who take hormone therapy. The highest concentration of estrogens in treated wastewater was detected in wastewater treatment plants that applied the simplest methods of wastewater treatment [27]. Estrogens from wastewater are removed through adsorption on activated sludge that allows the removal of ethinylestradiol, $17 \beta$-estradiol and estron by $67-80 \%, 80 \%$ and about $70-90 \%$, respectively. Ozonation is considered an efficient method 
for removal of ethinylestradiol and $17 \beta$-estradiol by $90-99 \%$. Ozonation combined with $\mathrm{H}_{2} \mathrm{O}_{2}$ allows the removal of these pharmaceuticals by $94 \%$. Application of biological filters allows the removal of estradiol, estron and ethinylestradiol by 92,67 and $92 \%$, respectively. Progesterone - that is another natural sex hormone - is removed in a similar manner to the removal of estrogens [7, 28, 29]. Membrane techniques also allow the removal of estrogens, however synthetic estrogens are removed with higher efficiency [30]. Estrogens in treated wastewater are discharged to surface water. The removal of estrogens in the natural environment depends on the occurrence of bacteria, rainfall and temperature (lower activity and faster decomposition of estrogens is observed in August than in May or April) [27]. The occurrence of phytoestrogens and mycoestrogens in surface water is considered a problem as these pharmaceuticals also show estrogenic activity. Mycoestrogens in surface water were detected at the concentration of $0.044 \mathrm{mg} / \mathrm{m}^{3}$ [31]. Current studies on the removal of these compounds from surface water use an integrated method based on sorption on activated carbon, photocatalytic oxidation and nanofiltration [32].

\section{Lipid regulators}

Clofibric acid, bezafibrate and gemfibrozil are removed from wastewater through adsorption on activated sludge from 26 to $52 \%, 50-97 \%$ and $45-64 \%$, respectively. The removal of lipid regulators through filtration is a low efficient method for elimination of these contaminates from wastewater (bezafibrate, clofibric acid and gemfibrozil are removed by 17,15 and $17 \%$, respectively). Adsorption on activated carbon allows the removal of clofibric acid and gemfibrozil up to 50 and $90 \%$, respectively). Ozonation combined with $\mathrm{H}_{2} \mathrm{O}_{2}$ allows the removal of gemfibrozil by about $99 \%$ [7, 13].

\section{Antibiotics}

Potential threats for aquatic environment are posed by antibiotics that include sulfonamides (sulfamethoxazole) and macrolides (erythromycin, clarithromycin), fluoroquinolones (ciprofloxacin, norfloxacin), tetracyclines (tetracycline, chlortetracycline, oxytetracycline), and also trimethoprim and lincomycin. Ciprofloxacin and norfloxacin were identified in surface water in the United States of America (at the concentration of 0.03 and $0.12 \mu \mathrm{g} / \mathrm{dm}^{3}$, respectively) [7]. Tetracyclines in surface water in the United States of America were detected by Lindey's group (chlortetracycline - $0.15 \mu \mathrm{g} / \mathrm{dm}^{3}$, oxytetracycline $-1.34 \mu \mathrm{g} / \mathrm{dm}^{3}$ ) and Kolpin with coworkers (tetracycline $-0.11 \mu \mathrm{g} / \mathrm{dm}^{3}$ ) [33]. Due to their chemical character antibiotics undergo adsorption on sediments, e.g. norfloxacin and ciprofloxacin were detected in sediments at the concentration of $1.88-11.20 \mathrm{ng} / \mathrm{g}$ [34]. These antibiotics are removed from raw wastewater by $50-70 \%$ through biodegradation, hydrolysis or photolysis [9, 35]. Adsorption on activated sludge can eliminate erythromycin by $25 \%$, clarithromycin by $54 \%$, trimethoprim by $69 \%$ and sulfamethoxazole by max. 55\%. Antibiotics reduce the number of microorganisms (bacteria and proteoza) that constitute the composition of activated sludge. Coagulation can eliminate erythromycin by $33 \%$. Chlorination is considered a very efficient method for removal of lincomycin, sulfamethoxazole and trimethoprim (up to 100\%). Ozonation is also an efficient method that allows the removal of antibiotics even up to $90 \%$ (i.e. sulfamethoxazole, erythromycin, trimethoprim, clarithromycin). Tetracyclines are removed through chlorination with the removal efficiency almost of $100 \%$ [7]. An alternative method for the removal of antibiotics is adsorption on activated carbons. The removal efficiency of trimethoprim reaches $83 \%$ whereas sulfamethoxazole even up to $99 \%$. 
However erythromycin is adsorbed only by 54\% [7]. Photocatalytic removal of sulfamethoxazole, doxycycline and ampicillin is currently investigated, however this method is not sufficient for the removal of sulfamethoxazole [36-38]. The efficiency of photocatalytic removal of sulfamethoxazole can be improved by addition of iron(III) salt [39]. Other method for removing sulfamethoxazole is electrocoagulation. Coagulation of sulfamethoxazole allows the removal of only $10 \%$. In case of electrocoagulation carried out with a steal anode the removal of sulfamethoxazole can reach $40 \%$ [40]. Fluoroquinolones are efficiently removed through photodegradation (up to 96\%) and chlorination (up to $100 \%$ ). Adsorption of fluoroquinolones on activated sludge is not efficient (about $50 \%$ ) $[2,7]$. The presence of sulfamethoxazole $\left(0.5-4 \mathrm{ng} / \mathrm{dm}^{3}\right)$, erythromycin $\left(0.5-72 \mathrm{ng} / \mathrm{dm}^{3}\right)$ and trimethoprim $\left(10-183 \mathrm{ng} / \mathrm{dm}^{3}\right)$ was detected in the rivers of Wales [35].

\section{Other pharmaceuticals}

Fluorouracil - a pharmaceutical used in cancer treatment - was detected in water sampled from the Air and Calger rivers in Yorkshire in Great Britain. This resulted from low adsorption of this pharmaceutical on activated sludge (about 10\%) and high toxicity to bacteria. Fluorouracil does not undergo biodegradation, and what is more, it shows a negative effect on biological treatment of wastewater [41].

Random tests of water quality in Great Britain confirmed the presence of synthetic glucocorticosteroids, i.e. prednisone, prednisolone, cortisol and cortisone, in the River Thames. These drugs show anti inflammatory and immunosuppressive effects. Glucocorticosteroids are removed from wastewater in a similar manner to the removal of female hormones, i.e. estrogens. Cortisol, cortisone and prednisone are removed by $70-76 \%$ whereas prednisolone by about $32 \%$. The most efficient method of removing these pharmaceuticals is adsorption on activated sludge [42].

Surface water in Germany, Switzerland and the United States of America shows the presence of lidocaine and tramadol. Lidocaine is a drug used in local anesthetic and myocardial infarction. Tramadol is a narcotic painkiller with agonistic and antagonistic effect. These drugs are easily soluble and susceptible to adsorption on activated sludge. The removal of tramadol and lidocaine from wastewater is about $40 \%$ [43].

Another group of pharmaceutical drugs that were detected in surface water are histamine antagonists such as cetirizine, acrivastine and fexofenadine. They are the II generation antihistamine drugs that are commonly used for relief of allergies. These drugs were detected in water sampled from the rivers in Finland. The removal of antihistamine drugs during wastewater treatment ranged from 16-18\% for cetirizine and fexofenadine to $36 \%$ for acrivastine [44]. As for antiviral drugs only isolated incidents of their presence in raw wastewater were reported. For example, zanamivir used in treatment of influenza was detected in raw wastewater in Japan. The concentration of this drug was $241.6 \mathrm{ng} / \mathrm{dm}^{3}$. Another drugs, i.e. acyclovir used in treatment of herpes infections and lamivudine used in treatment of HIV were detected in Germany in raw wastewater at the concentration of 1800 and $720 \mathrm{ng} / \mathrm{dm}^{3}$, respectively. The removal of antiviral drugs in wastewater treatment plants occurs during ozonation, adsorption on activated sludge, membrane processes and photocatalysis. Application of membrane filters allows the removal of acyclovir by $99 \%$. Conventional methods of wastewater treatment show low efficiency [45]. Table 2 presents the concentrations of pharmaceuticals detected in treated wastewater. 
Pharmaceuticals detected in treated wastewater

\begin{tabular}{|c|c|c|}
\hline Pharmaceutical & $\begin{array}{c}\text { Concentration } \\
{\left[\mu \mathrm{g} / \mathbf{d m}^{3}\right]}\end{array}$ & References \\
\hline Atenolol & $1.26-7.6$ & [35] \\
\hline Bezafibrate & $\begin{array}{c}0.086-0.667 \\
0.25-4.56\end{array}$ & $\begin{array}{l}{[35]} \\
{[46]}\end{array}$ \\
\hline Diclofenac & $\begin{array}{c}0.005-1.59 \\
0.12 \\
0.16 \\
0.09 \\
0.03-0.142\end{array}$ & $\begin{array}{l}{[46]} \\
{[47]} \\
{[48]} \\
{[49]} \\
{[35]}\end{array}$ \\
\hline Diazepam & $0.5-7.1$ & [50] \\
\hline Erythromycin & $\begin{array}{c}6.0 \\
0.292-2.841\end{array}$ & {$[46]$} \\
\hline Fluoxetine & $5.6-44.9$ & [50] \\
\hline Gemfibrozil & 1.5 & [46] \\
\hline Ibuprofen & $\begin{array}{c}0.131-0.424 \\
0.05-3.35 \\
0.11\end{array}$ & $\begin{array}{l}{[35]} \\
{[46]} \\
{[47]}\end{array}$ \\
\hline Ketoprofen & $\begin{array}{c}0.11 \\
0.033 \\
\end{array}$ & $\begin{array}{l}51] \\
{[35]}\end{array}$ \\
\hline Carbamazepine & $\begin{array}{c}0.644-4.596 \\
6.9\end{array}$ & $\begin{array}{l}135] \\
{[46]}\end{array}$ \\
\hline Clarithromycin & 0.24 & [46] \\
\hline Acetylsalicylic acid & $\begin{array}{c}0.05-1.51 \\
0.065\end{array}$ & {$[46]$} \\
\hline Clofibric acid & $\begin{array}{c}0.46-1.56 \\
0.075 \\
\end{array}$ & $\begin{array}{l}{[46]} \\
{[35]}\end{array}$ \\
\hline Metoprolol & 0.27 & [48] \\
\hline Naproxene & $\begin{array}{c}0.03 \\
0.11 \\
0.234-0.703 \\
0.07\end{array}$ & $\begin{array}{l}{[51]} \\
{[48]} \\
{[35]} \\
{[47]}\end{array}$ \\
\hline Paracetamol & 1.826 & [35] \\
\hline Sulfamethoxazole & $\begin{array}{c}2.00 \\
0.023\end{array}$ & $\begin{array}{l}{[46]} \\
{[35]}\end{array}$ \\
\hline Tramadol & 1.603 & [50] \\
\hline Trimethoprim & $\begin{array}{c}0.66 \\
0.385-1.218 \\
\end{array}$ & $\begin{array}{l}{[46]} \\
{[35]}\end{array}$ \\
\hline
\end{tabular}

\section{Pharmaceuticals in surface and ground water}

Methods that are applied in treatment of wastewater do not allow the total removal of pharmaceuticals present in wastewater. These contaminates with treated wastewater are discharged into surface water. In 1976 Garrison et al. detected clofibric acid at the concentration of $0.8-2.0 \mu \mathrm{g} / \mathrm{dm}^{3}$ in treated wastewater in the United States of America. The presence of pharmaceuticals in water sampled from rivers in Great Britain was detected in 1981. Diclofenac was identified in 27 water samples taken from the area of Cologne in Germany at the concentration above $15 \mu \mathrm{g} / \mathrm{dm}^{3}$ [6]. Ciprofloxacin and norfloxacin were detected in surface water in the Unites States of America at the concentration of $0.03 \mu \mathrm{g} / \mathrm{dm}^{3}$ and $0.12 \mu \mathrm{g} / \mathrm{dm}^{3}$, respectively [7]. Natural and synthetic estrogens were also detected in surface and ground water in France. Maximum concentration of $17 \beta$-estradiol 
and estron in water sampled from rivers in France was $11.6 \mathrm{ng} / \mathrm{dm}^{3}$ and $0.3-3.5 \mathrm{ng} / \mathrm{dm}^{3}$, respectively [52].

Table 3 presents the concentrations of pharmaceuticals detected in surface and ground water in various parts of the world.

Pharmaceuticals that are the most frequently detected in surface and ground water

\begin{tabular}{|c|c|c|c|}
\hline $\begin{array}{c}\text { Type of } \\
\text { pharmaceutical }\end{array}$ & Country/place of detection & $\begin{array}{c}\text { Concentration } \\
{\left[\mathrm{ng} / \mathbf{d m}^{3}\right]}\end{array}$ & References \\
\hline Atenolol & $\begin{array}{l}\text { Spain/the Tagus river } \\
\text { Italy/the Lambro river }\end{array}$ & $\begin{array}{l}679 \\
241\end{array}$ & $\begin{array}{l}{[53]} \\
{[54]}\end{array}$ \\
\hline Acrivastine & Finland/the Aura river & 5 & {$[44]$} \\
\hline Bezafibrate & $\begin{array}{l}\text { Spain/the Tagus river } \\
\text { Sweden/the Fyris river } \\
\text { Poland/the Warta river } \\
\text { Italy/the Lambro river }\end{array}$ & $\begin{array}{c}234 \\
231 \\
16 \\
57.2\end{array}$ & $\begin{array}{l}53] \\
{[55]} \\
{[56]} \\
{[54]}\end{array}$ \\
\hline Ciprofloxacin & $\begin{array}{l}\text { China/the Hai river } \\
\text { (sediment }[\mathrm{ng} / \mathrm{g}] \text { ) } \\
\text { France/Seine river } \\
\text { Italy/the Lambro river }\end{array}$ & $\begin{array}{c}6^{*} \\
\\
20 \\
14.4 \\
\end{array}$ & $\begin{array}{l}57] \\
{[58]} \\
{[54]}\end{array}$ \\
\hline Cetirizine & Finland/the Aura river & 4 & [44] \\
\hline $\begin{array}{l}\text { Ethinylestradiol } \\
\text { Estrone } \\
17 \beta \text {-estradiol }\end{array}$ & $\begin{array}{c}\text { Czech Republic/the Berounka river } \\
\text { France } \\
\text { Poland/the Odra river } \\
\text { Poland/the Vistula river } \\
\text { Czech Republic/the Vltava river }\end{array}$ & $\begin{array}{l}4.6 \\
0.3-3.5 \\
1.3 \\
1.3 \\
3.8 \\
\end{array}$ & $\begin{array}{l}59] \\
{[52]} \\
{[12]} \\
{[12]} \\
{[59]}\end{array}$ \\
\hline Fluorouracil & Great Britain/the Arie river & $5-50$ & [41] \\
\hline Fexofenadine & Finland/the Aura river & 11 & {$[44]$} \\
\hline Gemfibrozil & $\begin{array}{c}\text { China/the Hai river } \\
\text { Spain/the Jarama river } \\
\text { Italy/the Lake Maggiore }\end{array}$ & $\begin{array}{c}62.2 \\
3678 \\
1.2 \\
\end{array}$ & $\begin{array}{l}60] \\
{[53]} \\
{[61]}\end{array}$ \\
\hline Erythromycin & $\begin{array}{c}\text { China/the Pearl river } \\
\text { Vietnam/the Mekong river } \\
\text { Italy/the Po river }\end{array}$ & $\begin{array}{c}13-423 \\
9-11 \\
15.9 \\
\end{array}$ & $\begin{array}{l}{[62]} \\
{[62]} \\
{[54]}\end{array}$ \\
\hline Diazepam & $\begin{array}{c}\text { Germany } \\
\text { Spain/the Tagus river }\end{array}$ & $\begin{array}{c}880 \\
3.96-40.90\end{array}$ & $\begin{array}{l}{[63]} \\
{[64]}\end{array}$ \\
\hline Diclofenac & $\begin{array}{c}\text { Greece/the Aisohas river } \\
\text { China/the Huang He river } \\
\text { Hungary/the Danube river } \\
\text { Spain/the Tagus river } \\
\text { Ukraine/the Loppan river } \\
\text { (sediment [ng/g]) } \\
\text { Slovenia/the Krka river } \\
\text { USA/the Anacostia river } \\
\text { Poland/the Odra river } \\
\text { Germany }\end{array}$ & $\begin{array}{c}432 \\
22.8-136 \\
24-931 \\
313 \\
3000^{*} \\
\\
282 \\
54.9 \\
470 \\
150 \\
\end{array}$ & $\begin{array}{l}{[65]} \\
{[60]} \\
{[66]} \\
{[53]} \\
{[67]} \\
\\
{[68]} \\
{[69]} \\
{[48]} \\
{[70]}\end{array}$ \\
\hline Fluoxetine & Minnesota/surface water & 28 & [71] \\
\hline Ibuprofen & $\begin{array}{c}\text { Spain/the Ebro river } \\
\text { China/the Huang He river } \\
\text { Sweden/the Fyris river } \\
\text { Great Britain }\end{array}$ & $\begin{array}{c}90 \\
416 \\
87 \\
789 \\
\end{array}$ & $\begin{array}{l}772] \\
{[60]} \\
{[55]} \\
{[73]}\end{array}$ \\
\hline Clarithromycin & $\begin{array}{c}\text { Italy/the Lambro river } \\
\text { Japan/the Tamagawa river }\end{array}$ & $\begin{array}{l}8.3 \\
1.1 \\
\end{array}$ & $\begin{array}{l}54] \\
{[74]} \\
\end{array}$ \\
\hline Ketoprofen & $\begin{array}{l}\text { Sweden/the Fyris river } \\
\text { Poland/the Wierzyca river } \\
\text { France/groundwater }\end{array}$ & $\begin{array}{l}163 \\
25 \\
2.8\end{array}$ & $\begin{array}{l}{[55]} \\
{[47]} \\
{[75]}\end{array}$ \\
\hline
\end{tabular}




\begin{tabular}{|c|c|c|c|}
\hline $\begin{array}{c}\text { Type of } \\
\text { pharmaceutical }\end{array}$ & Country/place of detection & $\begin{array}{c}\text { Concentration } \\
{\left[\mathrm{ng} / \mathbf{d m}^{3}\right]}\end{array}$ & References \\
\hline Carbamazepine & $\begin{array}{l}\text { USA/the Anacostia river } \\
\text { China/the Xuzhou river } \\
\text { Romania/the Soames river } \\
\text { Portugal/the Douro river } \\
\text { Kenya/the Nairobi river } \\
\text { Germany/the Leine river }\end{array}$ & $\begin{array}{c}97 \\
1.090 \\
72 \\
178 \\
100 \\
144\end{array}$ & $\begin{array}{l}{[76]} \\
{[77]} \\
{[78]} \\
{[79]} \\
{[80]} \\
{[81]}\end{array}$ \\
\hline $\begin{array}{l}\text { Cortizone } \\
\text { Cortisol }\end{array}$ & $\begin{array}{l}\text { Great Britain/the River Thames } \\
\text { Great Britain/the River Thames }\end{array}$ & $\begin{array}{l}4.2 \\
3.4\end{array}$ & $\begin{array}{l}{[42]} \\
{[42]}\end{array}$ \\
\hline Clofibric acid & $\begin{array}{c}\text { Spain/the Henares river } \\
\text { Wales/the River Taff }\end{array}$ & $\begin{array}{c}24 \\
8-11\end{array}$ & $\begin{array}{l}{[53]} \\
{[35]}\end{array}$ \\
\hline Lincomycin & $\begin{array}{c}\text { Italy/the Po river } \\
\text { Italy/the Lambro river }\end{array}$ & $\begin{array}{c}20 \\
24.4\end{array}$ & $\begin{array}{l}{[11]} \\
{[54]}\end{array}$ \\
\hline Lidocaine & Switzerland/the Lake Constance & 1.9 & [43] \\
\hline Metoprolol & $\begin{array}{c}\text { Spain/the Guadarrama river } \\
\text { Wales/the River Taff } \\
\text { Germany/the Leine river }\end{array}$ & $\begin{array}{c}41 \\
8-11 \\
63\end{array}$ & $\begin{array}{l}{[53]} \\
{[35]} \\
{[81]}\end{array}$ \\
\hline Norfloxacin & $\begin{array}{c}\text { China/the Pearl river (sediment ng/g) } \\
\text { France/the Seine river } \\
\text { Brazil/the Atibaia river }\end{array}$ & $\begin{array}{l}88 * \\
40 \\
50\end{array}$ & $\begin{array}{l}{[57]} \\
{[58]} \\
{[82]}\end{array}$ \\
\hline Naproxene & $\begin{array}{l}\text { Greece/the Aisonas river } \\
\text { Hungary/the Danube river } \\
\text { China/the Huang He river } \\
\text { Poland/the Warta river }\end{array}$ & $\begin{array}{c}72 \\
5.7-62 \\
10.5-18 \\
100\end{array}$ & $\begin{array}{l}{[65]} \\
{[66]} \\
{[60]} \\
{[56]}\end{array}$ \\
\hline Paracetamol & $\begin{array}{c}\text { Spain/the Guadarrama river } \\
\text { Republic of Serbia/groundwater } \\
\text { Great Britain }\end{array}$ & $\begin{array}{c}188 \\
78-160 \\
121\end{array}$ & $\begin{array}{l}{[53]} \\
{[75]} \\
{[73]}\end{array}$ \\
\hline Propanolol & $\begin{array}{c}\text { Spain/the Henares river } \\
\text { Portugal/the Douro river } \\
\text { Wales/the River Taff }\end{array}$ & $\begin{array}{c}15 \\
3.18 \\
9-40 \\
\end{array}$ & $\begin{array}{l}{[53]} \\
{[79]} \\
{[35]}\end{array}$ \\
\hline $\begin{array}{l}\text { Prednisolone } \\
\text { Prednisone }\end{array}$ & $\begin{array}{l}\text { Great Britain/the River Thames } \\
\text { Great Britain/the River Thames }\end{array}$ & $\begin{array}{l}0.64 \\
0.86 \\
\end{array}$ & $\begin{array}{l}{[42]} \\
{[42]}\end{array}$ \\
\hline Progesterone & Pennsylvania & 9.4 & [29] \\
\hline Sulfamethoxazole & $\begin{array}{c}\text { South Korea/theYoungsan river } \\
\text { Portugal/the Douro river } \\
\text { Germany/the Leine river } \\
\text { Italy/the Lake Maggiore }\end{array}$ & $\begin{array}{c}0-110 \\
53.3 \\
63 \\
10\end{array}$ & $\begin{array}{l}{[62]} \\
{[79]} \\
{[81]} \\
{[61]}\end{array}$ \\
\hline Trimethoprim & $\begin{array}{c}\text { Vietnam/the Mekong river } \\
\text { Japan/the Tamagawa river } \\
\text { Portugal/the Douro river }\end{array}$ & $\begin{array}{c}5-20 \\
100 \\
15.7\end{array}$ & $\begin{array}{l}{[62]} \\
{[62]} \\
{[79]}\end{array}$ \\
\hline Tramadol & Switzerland/the Lake Constance & 2 & [43] \\
\hline
\end{tabular}

*sediment

The concentration of pharmaceuticals in surface water depends on the sampling point. Significantly higher concentrations were determined in the rivers that flow through urban areas, e.g. cities of Spain (Madrid, Barcelona) or Germany (Berlin). The presence of 32 pharmaceuticals (that belong to different therapeutic groups) was detected in the samples of surface water and treated wastewater taken from various sampling points in Germany. At present the concentration of pharmaceuticals in surface water is about several hundred $\mathrm{ng} / \mathrm{dm}^{3}$. The presence of pharmaceuticals in surface water is also affected by seasons. Water sampled in winter and autumn - when the temperature is lower and sunlight is less intense - shows significantly higher concentrations of pharmaceuticals. This is mostly due to the limitations in photolysis and also reproduction of bacteria that facilitate 
decomposition of pharmaceuticals. For example, in Sweden, the concentrations of atenolol, metoprolol and carbamazepine in the Fyris river were compared at different times of the year. The lowest concentration of metoprolol, atenolol and carbamazepine were observed in summer and autumn. This decrease in the concentrations was mostly due to biodegradation and photolysis. Carbamazepine underwent partial biotransformation and slow photolysis in natural conditions [55, 83]. The decay time for diclofenac in water of Eastern Europe is about 2.5-3 hours during summer and spring, and increases up to 14 hours during autumn and winter [84].

\section{Presence of narcotics in surface, ground and drinking water}

The EMCDDA reports (European Monitoring Centre for Drugs and Drug Addiction) confirm that the most frequently taken illegal drugs are cocaine, cannabinoids, amphetamine and heroine. According to the EMCDDA data $22.5 \mathrm{mln}$ Europeans at age of 15-64 took cocaine $(12 \mathrm{mln})$, amphetamine $(11 \mathrm{mln})$, ecstasy $(9.5 \mathrm{mln})$ in past couple of years. Similarly to pharmaceuticals, illegal drugs are excreted in urine in metabolized or non metabolized forms. Then, they get into wastewater and eventually to surface water. Zuccato et al. was the first scientist who identified the presence of narcotics in surface water. In 2005 they identified the presence of cocaine in the Po river at the concentration of $1.2 \mathrm{ng} / \mathrm{dm}^{3}$ and raw and treated wastewater at the concentration of $120 \mathrm{ng} / \mathrm{dm}^{3}$ and $42 \mathrm{ng} / \mathrm{dm}^{3}$, respectively $[85,86]$. Other studies confirmed the presence of narcotics in Italy, United States of America, Spain, Ireland and Belgium [87-89]. Some compounds like codeine, cocaine or morphine are both medical and intoxicating drugs. Codeine is used to treat pain and relieve cough. It is a natural opiate alkaloid and does not show strong addiction effects. Morphine is a phenanthrene alkaloid and is used to treat pain. It shows addiction effects. Cocaine is an alkaloid from the coca plant (Erythroxylum coca) that shows the effect of local anesthesia. It is used in laryngology and ophthalmology. Amphetamine and its derivatives, i.e. methamphetamine and ephedrine, belong to the group of psychostimulants that enhance dopaminergic and noradrenergic transmittance and to a lesser extent serotonergic transmittance. They are used in treatment of attention deficit hyperactivity disorder (ADHD) in children [8, 87, 89].

Some of these substances are removed from wastewater in municipal wastewater treatment plants. Cocaine and its metabolites are removed by $72-100 \%$ mainly through adsorption on activated sludge. The efficiency of filtration is about $25 \%$. Amphetamine is removed by $52-99 \%$ through adsorption on activated sludge whereas filtration allows the removal up to $95 \%$. The efficiency of adsorption of methamphetamine on activated sludge is lower than in case of amphetamine (max up to 50\%). Morfine is adsorbed on activated sludge by $72-99 \%$ whereas codeine by only $33 \%$ [90, 91]. Cocaine was detected in raw wastewater and treated wastewater in Spain at the concentration of 384 and $16.8 \mathrm{ng} / \mathrm{dm}^{3}$, respectively. Amphetamine was identified in raw wastewater in Belgium at the concentration of $681 \mathrm{ng} / \mathrm{dm}^{3}$. Morfine was detected in raw wastewater and treated wastewater in Spain at the concentration of 94.4 and $46.4 \mathrm{ng} / \mathrm{dm}^{3}$, respectively [92, 93].

Illegal drugs are also detected in surface and ground water, and even in drinking water (Table 4). The presence of narcotics in drinking water becomes a real threat. Drinking water in Spain showed the presence of cocaine, nicotine and caffeine at the concentration of $0.4-2.3,6.0$ and $50 \mathrm{ng} / \mathrm{dm}^{3}$, respectively [94]. 
Illegal drugs detected in surface, ground and drinking water [94]

\begin{tabular}{|c|c|c|}
\hline Narcotics & Country/place of detection & $\begin{array}{c}\text { Concentration } \\
{\left[\mathbf{n g}^{\mathbf{n}} \mathbf{\mathbf { d m } ^ { 3 }}\right]}\end{array}$ \\
\hline \multirow{3}{*}{ Cocaine } & Spain/the Henares river & 44 \\
& Great Britain/the River Taff & 2 \\
& Barcelona/groundwater & 3.8 \\
& Spain/drinking water & $0.4-2.3$ \\
\hline \multirow{2}{*}{ Amphetamine } & Great Britain/the River Taff & 4 \\
& Spain/the Ebro river & 6.8 \\
\hline \multirow{3}{*}{ Morfine } & Germany/the Rhine river & 10 \\
& Spain/the Ebro river & 9.8 \\
& Spain/the Henares river & 16 \\
& Barcelona/groundwater & 3.4 \\
\hline \multirow{2}{*}{ Methamphetamine } & Spain/the River Taff & 2.1 \\
\hline
\end{tabular}

\section{Ecotoxicity of pharmaceuticals}

Pharmaceuticals with raw and treated wastewater, and surface flow are discharged to surface water, and thus have an effect on aquatic organisms i.e. phytoplankton, zooplankton, benthos and also fish. Due to relatively low rate of degradation these substances in water can undergo accumulation. Propanolol (due to high lipophilicity) undergoes accumulation at the highest rate [4]. It shows toxicity towards zooplankton and phytoplankton. Additionally, propranolol shows chronic toxicity to cardiovascular system and impairs fertility of C. dubia [95].

Diclofenac is a pharmaceutical that is the most difficult to remove from wastewater. Diclofenac is discharged with treated wastewater to surface water where it can undergo accumulation in sediments [96]. Biodegradation of diclofenac can last up to several months [5]. The presence of diclofenac in water poses many threats to aquatic organisms including fish because this pharmaceutical shows the highest acute toxicity among non steroidal anti inflammatory drugs (NSAIDs). The $\mathrm{EC}_{50}$ (median effective concentration) for diclofenac is $14.5 \mathrm{mg} / \mathrm{dm}^{3}$ for phytoplankton and $22.43 \mathrm{mg} / \mathrm{dm}^{3}$ for zooplankton. Diclofenac shows chronic toxicity to phytoplankton and benthos. Long-term exposure of rainbow trout (Oncorhynchus mykiss) to diclofenac causes damages to kidneys and alterations in gills [95].

Acute toxicity of naproxene differs depending on a living organism and for cyanobacteria and rainbow trout is 12.3 and $690 \mathrm{mg} / \mathrm{dm}^{3}$, respectively. Naproxene shows chronic toxicity to phytoplankton. Toxicity of naproxene is increased by the presence of other pharmaceuticals from the group of non steroidal anti inflammatory drugs (i.e. diclofenac, ibuprofen and acetylsalicylic acid) or the presence of triclosan, gemfibrozil, diclofenac, ibuprofen and salicylic acid [97].

Carbamzepine is potentially toxic to aquatic microorganisms. Acute toxicity for D. magna is $17.2 \mathrm{mg} / \mathrm{dm}^{3}$ whereas chronic toxicity for $C$. dubia is $25 \mu \mathrm{g} / \mathrm{dm}^{3}$ [90]. The effect of carbamazepine on fish from $D$. rerio species was investigated, and this substance did not cause any morphological changes either in adult organisms or in embryos [98].

Diazepam - similarly to diclofenac - shows acute toxicity to rainbow trout. Laboratory studies confirmed that diazepam causes histopathological changes in rainbow trout organisms, especially in a liver. It is toxic to river fish from $G$. holbrooki species and 
European (A. Anguilla). Also, diazepam shows toxicity to shrimps from S. proboscideus family, plankton and D. magna [25].

Fluoxetine shows toxicity towards snails from $P$. antipodarum species and earthworms from L. variegatus species [99]. The studies conducted on fish from A. dispar species confirmed the effect of fluoxetine on the nervous system of fish. This resulted in modifications to behavior of fish e.g. decreased response to stimuli, reduced the average speed of swimming, and drifting. The study results confirmed that fluoxetine and other pharmaceutical from the SSRI group show chronic toxicity to oyster from $C$. gigas species which results in alteration of structure and growth of oyster larvae [100-102].

Estrogens present in aquatic environment can undergo accumulation in organisms of fish. The bioaccumulation factor determined for fish is 2.22 for estron and 2.83 for ethinyl estradiol [63]. In addition, the presence of estrogens can cause feminization of male fish, and this results in the decrease in fertility, pathological alterations in structure and function of male gonads [27]. This was confirmed by laboratory tests. The concentration of estrogens in aquatic environment in the range from 4 to $10 \mathrm{ng} / \mathrm{dm}^{3}$ caused feminization of male fish and led to inhibition of reproduction [10, 29].

Glucocorticosteroids - similarly to estrogens - can accumulate in organisms of fish. The toxicity of glucocorticosteroids towards other aquatic microorganisms has not been confirmed yet [42].

Pharmaceuticals that belong to the group of lipid regulators show toxicity to aquatic microorganisms. Gemfibrozil and bezafibrate at the concentration above $10 \mathrm{mg} / \mathrm{dm}^{3}$ show ecotoxicity to Anabaena. Also, they are toxic to cyanobacteria $V$. fischeri and D. magna [13].

Clofibric acid shows acute toxicity towards phytoplankton, zooplankton and benthos at the concentration from 87.22 to $526.5 \mathrm{mg} / \mathrm{dm}^{3}$ (depending on species), and also impairs reproductively of $D$. magna (the concentration of $10 \mu \mathrm{g} / \mathrm{dm}^{3}$ ) [95].

Ciprofloxacin can undergo sedimentation and accumulation in sediments, and thus indicate toxicity to earthworms of $L$. variegatus and snails from the $P$. antipodarum species. Furthermore, fluoroquinolones accumulate in a liver of some fish species, e.g. L. argentimaculatus [34].

Sulfamethoxazole shows toxicity towards algae and aquatic microorganisms and shows low toxicity towards higher organisms. The presence of sulfamethoxazole in the environment increases drug resistance of bacteria. There is a gradual increase in the number of bacteria strains that are resistant to sulfamethoxazole effects [103, 104]. Tetracyclines show acute toxicity towards $D$. magna, D. rerioand $C$. auratus. In addition, tetracyclines (i.e. chlortetracycline and oxytetracycline) affect gene expression and lead to the increase in steroid growth hormones in fish. This was confirmed by studies on Japanese fish from the $O$. Latipesspecies. Male fish from $O$. Latipesspecies were swimming in water with the concentration of chlortetracycline $\left(40 \mathrm{mg} / \mathrm{dm}^{3}\right)$ and oxytetracycline $\left(50 \mathrm{mg} / \mathrm{dm}^{3}\right)$ for 14 days. After termination of the exposure time a significant increase in estradiol in fish blood was determined [33]. The presence of antibiotics in the environment can cause the increase in drug resistance of bacteria, including pathogenic bacteria [2].

E. coli strains isolated from surface and ground water in Northern California showed resistance towards tetracyclines, chloramphenicol, ampicillin and amoxicillin [15].

Although anticancer drugs were subjected to toxicity tests on S. typhimurium bacteria and common fruit fly (D. melanogaster), there is no evidence on toxicity of these drugs towards aquatic organisms [41]. 
Tramadol and lidocaine show chronic toxicity towards D. rerio, B. rerio [43].

Recent studies confirmed that cocaine present in aquatic environment is also toxic to aquatic organisms. Tests conducted on D. polymorpha showed that cocaine causes damages of cell DNA, an increase in apoptosis of cells and reduction in stability of lysosome membrane [88].

Due to high environmental toxicity naproxene and gemfibrozil were enlisted on the Contaminant Candidate List published by the US EPA (United States Environmental Protection Agency) [13].

\section{Pharmaceuticals in drinking water}

The studies on occurrence of pharmaceuticals in drinking water have been conducted for 25 years. Despite advanced techniques for wastewater treatment some quantities of pharmaceuticals are introduced to surface water, and then to drinking water. Currently, the concentration of pharmaceuticals in drinking water ranges from several to over hundred $\mathrm{ng} / \mathrm{dm}^{3}$ (Table 5).

For example, the concentration of clofibric acid in drinking water sampled from the water intakes in Berlin was about $10 \mathrm{ng} / \mathrm{dm}^{3}$ [5]. The presence of pharmaceuticals in drinking water in the United States of America is considered a serious problem. The studies confirmed that the concentration of pharmaceuticals in samples of drinking water was $0.3 \mu \mathrm{g} / \mathrm{dm}^{3}$ [105]. It is difficult to indicate if such concentration of pharmaceuticals from different therapeutic groups has a specific effect on human health.

Pharmaceuticals detected in drinking water

\begin{tabular}{|c|c|c|c|}
\hline Pharmaceutical & Country & $\begin{array}{c}\text { Concentration } \\
{\left[\mathrm{ng} / \mathbf{d m}^{3}\right]}\end{array}$ & References \\
\hline Atenolol & $\begin{array}{c}\text { France } \\
\text { Germany } \\
\text { United States }\end{array}$ & $\begin{array}{c}2 \\
5 \\
2.8\end{array}$ & $\begin{array}{c}{[106]} \\
{[7]} \\
{[106]}\end{array}$ \\
\hline Bezafibrate & Germany/Berlin & 27 & {$[53]$} \\
\hline Diclofenac & $\begin{array}{c}\text { Germany } \\
\text { Germany } \\
\text { Poland }\end{array}$ & $\begin{array}{c}2 \\
6-35 \\
4 \\
\end{array}$ & $\begin{array}{c}{[5]} \\
{[53]} \\
{[107]} \\
\end{array}$ \\
\hline Diazepam & $\begin{array}{c}\text { Canada } \\
\text { Germany }\end{array}$ & $\begin{array}{l}10 \\
20 \\
\end{array}$ & $\begin{array}{c}{[108]} \\
{[7]}\end{array}$ \\
\hline $\begin{array}{c}\text { Estriol } \\
\\
17 \beta \text {-estradiol } \\
\text { Ethinylestradiol }\end{array}$ & $\begin{array}{l}\text { France } \\
\text { Germany } \\
\text { Spain } \\
\text { Germany } \\
\text { Germany } \\
\end{array}$ & $\begin{array}{c}11.6 \\
0.3 \\
11 \\
2.1 \\
0.5 \\
\end{array}$ & $\begin{array}{l}{[108]} \\
{[108]} \\
{[108]} \\
{[109]} \\
{[109]}\end{array}$ \\
\hline Erythromycin & $\begin{array}{c}\text { Germany } \\
\text { Canada } \\
\text { United States }\end{array}$ & $\begin{array}{l}20 \\
12 \\
0.3\end{array}$ & $\begin{array}{c}7] \\
{[110]} \\
{[106]}\end{array}$ \\
\hline Gemfibrozil & $\begin{array}{c}\text { Germany } \\
\text { United States } \\
\text { Canada }\end{array}$ & $\begin{array}{c}5 \\
1.8 \\
2\end{array}$ & $\begin{array}{c}7] \\
{[106]} \\
{[110]}\end{array}$ \\
\hline Ibuprofen & $\begin{array}{c}\text { Canada } \\
\text { Germany } \\
\text { United States }\end{array}$ & $\begin{array}{c}1-3 \\
3 \\
10.7\end{array}$ & $\begin{array}{c}{[7]} \\
{[109]} \\
{[106]}\end{array}$ \\
\hline
\end{tabular}




\begin{tabular}{|c|c|c|c|}
\hline Pharmaceutical & Country & $\begin{array}{c}\text { Concentration } \\
{\left[\mathbf{n g} / \mathbf{d m}^{\mathbf{3}}\right]}\end{array}$ & References \\
\hline & Germany/Berlin & 30 & {$[77]$} \\
& Germany & $13-54$ & {$[35]$} \\
& France & 10.7 & {$[110]$} \\
Carbamazepine & Canada & 37 & {$[111]$} \\
& United States & $1.1-19$ & {$[5]$} \\
& Germany/Berlin & 10 & {$[53]$} \\
& Germany & 50 & {$[35]$} \\
\hline \multirow{2}{*}{ Clofibric acid } & Italy/Milan & 5.3 & {$[106]$} \\
& Germany & 165 & {$[107]$} \\
& France & 19 & {$[106]$} \\
\hline \multirow{2}{*}{ Salicylic acid } & Germany & 13 & {$[7]$} \\
\hline \multirow{2}{*}{ Naproxene } & Poland & 1.3 & {$[106]$} \\
\hline Propanolol & United States & 5 & {$[106]$} \\
\hline \multirow{2}{*}{ Sulfamethoxazole } & Germany & 6 & {$[7]$} \\
\hline \multirow{2}{*}{ Trimethoprim } & France & 1.0 & 2 \\
\hline
\end{tabular}

The problem of pharmaceuticals in drinking water can have a significant impact on human health due to long term exposure to pharmaceuticals. If the concentration of a pharmaceutical in drinking water is $5 \mathrm{ng} / \mathrm{dm}^{3}$ and a human being drinks about 2 liters per day - this means that a daily intake of this pharmaceutical is about $10 \mathrm{ng}$. This small daily dose results in about $3650 \mathrm{ng} / \mathrm{year}$. If this value is multiplied by the average life expectancy (about 70 years) the total dose would be $255,500 \mathrm{ng}$. This unaware intake of pharmaceuticals that belong to different therapeutic groups can have additional effect on a human organism. Particular attention should be paid to the occurrence of estrogens in drinking water. Estrogens in drinking water can cause the increase in breast and testicular cancer and also reduction in fertility in men $[109,112,113]$. Pharmaceuticals in drinking water can pose a threat to infants, babies, the elderly, and people who suffer from kidney or liver failure and cancer. The occurrence of anticancer drugs in drinking water would be particularly dangerous to pregnant women due to the fact that some cytoxic agents (i.e. fluorouracil) can penetrate blood-placenta barrier, and thus cause teratogenic and embryotoxic effect $[114,115]$.

\section{Summary and conclusions}

Many pharmaceuticals belong to various groups of compounds that are difficult to remove from wastewater. Methods that are applied for treating wastewater in municipal wastewater treatment plants do not allow complete removal of these pharmaceuticals. Pharmaceuticals are more often detected in surface water and drinking water. Pharmaceuticals that are the most frequently detected in surface water include non steroidal anti inflammatory drugs (NSAIDs): diclofenac (the concentration in surface water in Greece is about $\mathrm{ng} / \mathrm{dm}^{3}$ ) and ketoprofen (the concentration in the Tagus river in Spain was $\left.\mathrm{ng} / \mathrm{dm}^{3}\right)$. Also, pharmaceuticals from the group of lipid regulators are beta-blockers (atenolol detected in the Taff river in Wales at the concentration of $190-560 \mathrm{ng} / \mathrm{dm}^{3}$ ). Pharmaceuticals were also detected in groundwater (e.g. the concentration of diclofenac in ground water in Germany was $590 \mathrm{ng} / \mathrm{dm}^{3}$ ). The presence of pharmaceuticals in surface water shows toxic effect on aquatic organisms. Antibiotics can lead to e.g. the increase in 
drug resistance of microorganisms, including pathogenic microoganisms. Therapeutic substances were also detected in drinking water. The presence of pharmaceuticals in drinking water is a significant problem of highly urbanized cities such as Berlin, Madrid or Barcelona. Some of pharmaceuticals that are resent in drinking water can cause the increase in diseases, e.g. cancer (female sex hormones). The occurrence of narcotics in surface, ground and drinking water is another problem. There are no regular tests on the presence of pharmaceuticals in surface and drinking water. This problem gradually grows due to increasing intake of pharmaceuticals by the society. European law did not establish a threshold for contamination by pharmaceuticals and hormones but in January 2012 the European Commission added 15 chemical compounds to the list of 33 compounds that contaminate the environment. The concentration of these substances - especially diclofenac, ethinylestradiol and $17 \beta$-estradiol - should be monitored [116].

\section{References}

[1] Vazquez-Roig P, Blasco C, Picó Y. Advances in the analysis of legal and illegal drugs in the aquatic environment. Trends Anal Chemistry. 2013;50:65-77. DOI: 10.1016/j.trac.2013.04.008.

[2] Sukul P, Spiteller M. Fluoroquinolone antibiotics in the environment. Rev Environ Contam Toxicol. 2007;191:131-162. DOI: 10.1007/978-0-387-69163-3_5.

[3] http://www.rynekzdrowia.pl/Farmacja/IMS-Health-o-aptecznym-rynku-lekow-w-I-kwartale2013r,129867,6.htm

[4] Scheurer M, Ramil M, Metcalfe CD, Groh S, Ternes TA. The challenge of analyzing beta-blocker drugs in sludge and wastewater. Anal Bioanal Chem. 2010;396:845-856. DOI: 10.1007/s00216-009-3225-7.

[5] Zhang Y, Geißen SU, Gal C. Carbamazepine and diclofenac: Removal in wastewater treatment plants and occurrence in water bodies. Chemosphere. 2008;73:1151-1161. DOI: 10.1016/j.chemosphere.2008.07.086.

[6] Nikolaou A, Meric S, Fatta D. Occurrence patterns of pharmaceuticals in water and wastewater environments. Anal Bioanal Chem. 2007;387:1225-1234. DOI: 10.1007/s00216-006- 1035-8.

[7] Monteiro SC, Boxall A. Occurrence and fate of human pharmaceuticals in the environment. Rev Environ Contam Toxicol. 2010;202:53-154. DOI: 10.1007/978-1-4419-1157-5_2.

[8] Janiec W. Kompendium farmakologii. (Compedmium of pharmacology). Warszawa: Wyd Lekarskie PZWL; 2005.

[9] Sukul P, Spiteller M. Sulfonamides in the environment as veterinary drugs. Rev Environ Contam Toxicol. 2006;187:67-101.

[10] Sumpter JP. Pharmaceuticals in the Environment: Moving from a Problem to a Solution. In: Kümmerer K, Hempel M, editors. Green and Sustainable Pharmacy. Berlin Heidelberg: Springer; 2010. DOI: 10.1007/978-3-642-05199-9_2.

[11] Calza P, Medana C, Padovano E, Giancotti V, Minero C. Fate of selected pharmaceuticals in river waters. Environ Sci Pollut Res. 2013;20:2262-2270. DOI: 10.1007/s11356-012-1097-4.

[12] Dudziak M, Luks-Betlej K. Occurrence of estrogens - steroid sex hormones - in the riverine water in Poland. Environ Pollut Control. 2004;26:21-24.

[13] Rosal R, Rodea-Palomares I, Boltes K, Fernández-Piñas F, Leganés F, Gonzalo S, et al. Ecotoxicity assessment of lipid regulators in water and biologically treated wastewater using three aquatic organisms. Environ Sci Pollut Res. 2010;17:135-144. DOI: 10.1007/s11356-009-0137-1.

[14] Wei Y, Zhang Y, Xu J, Guo Ch, Li L, Fan W. Simultaneous quantification of several classes of antibiotics in water, sediments, and fish muscles by liquid chromatography-tandem mass spectrometry. Front Environ Sci Eng. 2014;8:357-371. DOI: 10.1007/s11783-013-0580-6.

[15] Xunde L, Watanabe N, Xiao Ch, Harter T, McCowan B, Liu Y, et al. Antibiotic-resistant E. coli in surface water and groundwater in dairy operations in Northern California. Environ Monit Assess. 2014;186:1253-1260. DOI: 10.1007/s10661-013-3454-2.

[16] Włodarczyk-Makuła M. Wybrane mikrozanieczyszczenia organiczne w wodach i glebach (Selected organic micro-pollutions in water and soil). Warszawa: Monografie PAN (PAS Monographs) vol. 104. 2013.

[17] Verlicchi P, Al Aukidy M, Zambello E. Occurrence of pharmaceutical compounds in urban wastewater: Removal, mass load and environmental risk after a secondary treatment - A review. Sci Total Environ. 2012;429:123-155. DOI: 10.1016/j.scitotenv.2012.04.028. 
[18] Hernando MD, Agüera A, Fernández-Alba AR. LC-MS analysis and environmental risk of lipid regulators. Anal Bioanal Chem. 2007;387:1269-1285. DOI: 10.1007/s00216-006-0781-y.

[19] Ziylan A, Ince NH. The occurrence and fate of anti-inflammatory and analgesic pharmaceuticals in sewage and fresh water: treatability by conventional and non-conventional processes. $\mathrm{J}$ Hazard Mater. 2011;187(1-3):24-36. DOI: 10.1016/j.jhazmat.2011.01.057.

[20] Salgado R, Marques R, Noronha JP, Carvalho G, Oehmen A, Reis MA. Assessing the removal of pharmaceuticals and personal care products in a full-scale activated sludge plant. Environ Sci Pollut Res. 2012;19:1818-1827. DOI: 10.1007/s11356-011-0693-z.

[21] Radjenović J, Matosić M, Mijatović I, Petrović M, Barceló D. Membrane bioreactor (MBR) as an advanced wastewater treatment technology. Hdb Env Chem. 2008;5:37-101. DOI: 10.1007/698_5_093.

[22] Klavarioti M, Mantzavinos D, Kassinos D. Removal of residual pharmaceuticals from aqueous systems by advanced oxidation processes. Environ Int. 2009;35:402- 417. DOI: 10.1016/j.envint.2008.07.009.

[23] Tambosi JL, de Sena RF, Favier M, Gebhardt W, José HJ, Schröder HF. Removal of pharmaceutical compounds in membrane bioreactors (MBR) applying submerged membranes. Desalination. 2010;261:148-156. DOI: 10.1016/j.desal.2010.05.014.

[24] Adamek E, Jakubczyk J, Baran W, Makowski A, Lipska I, Ziemiańska J, et al. Fotodegradacja wybranych leków przeciwzapalnych w środowisku wodnym (Photodegradation of the selected anti-inflammatory drugs in the aquatic environment). Proc ECOpole. 2011;5:147-152. http://tchie.uni.opole.pl/PECO11_1/PL/AdamekJakubczyk_PECO11_1.pdf.

[25] Straub OJ. Deterministic and Probabilistic Environmental Risk Assessment for Diazepam. In: Kümmerer K, editor. Pharmaceuticals in Environment. Berlin Heidelberg: Springer; 2008. DOI: 10.1007/978-3-540-74664-5_22.

[26] Nentwig G. Another Example of Effects of Pharmaceuticals on Aquatic Invertebrates: Fluoxetine and Ciprofloxacin. In: Kümmerer K, editor. Pharmaceuticals in Environment. Berlin Heidelberg: Springer; 2008. DOI: 10.1007/978-3-540-74664-5_13.

[27] Tyler CR, Jobling S. Roach, sex, and gender-bending chemicals: the feminization of wild fish in English river. Bioscience. 2008;58:1051-1059. DOI: 10.1641/B581108.

[28] Gmurek M, Olak M, Miller JS. Endocrine disrupting compounds (EDCs) - environmental hazards and their photochemical degradation. Proc ECOpole. 2012;6(1):85-90. DOI: 10.2429/proc.2012.6(1)011.

[29] Velicu M, Suri R. Presence of steroid hormones and antibiotics in surface water of agricultural, suburban and mixed-use areas. Environ Monit Assess. 2009;154:349-359. DOI: 10.1007/s10661-008-0402-7.

[30] Dudziak M, Bodzek M. Removal of phytoestrogens from water solutions using tubular nanofiltration membranes. Ecol Chem Eng A. 2010;17:289-295.

[31] Dudziak M. Removal of mycoestrogenes from aqueous solutions in the integrated photocatalysis-microfiltration-nanofiltration. Environ Pollut Control. 2012;35:29-32.

[32] Dudziak M. The study on the effectivness of the mycoestrogens removal from water via integrated sorption-phytocatalysis-nanofiltration system. Annual Environ Protect. 2013;15:1929-1936.

[33] Daghrir R, Drogui P. Tetracycline antibiotics in the environment: a review. Environ Chem Lett. 2013;11:209-227. DOI: 10.1007/s10311-013-0404-8.

[34] He X, Wang Z, Nie X, Yang Y, Pan D, Leung AO, Cheng Z. Residues of fluoroquinolones in marine aquaculture environment of the Pearl River Delta, South China. Environ Geochem Health. 2012;34:323-335. DOI: $10.1007 / \mathrm{s} 10653-011-9420-4$.

[35] Kasprzyk-Hordern B, Dinsdale RM, Guwy AJ. The removal of pharmaceuticals, personal care products, endocrine disruptors and illicit drugs during wastewater treatment and its impact on the quality of receiving waters. Water Res. 2009;43:363-380. DOI: 10.1016/j.watres.2008.10.047.

[36] Makowski A, Sobczak A, Wcisło D, Adamek E, Baran W, Nocoń W. Fotokatalityczna degradacja ampicyliny w roztworach wodnych (Photocatalytic degradation of ampiciline in water solutions). ProcECOpole. 2009;3:81-86.

[37] Baran W, Adamek E, Ziemiańska J, Makowski A, Sobczak A. Zmiany ekotoksyczności roztworów zawierających sulfonanidy $\mathrm{w}$ trakcie procesu zaawansowanego utleniania (Changes in ecotoxicity of sulfonamides solutions during the advances oxidation process). Proc ECOpole. 2012;6:313-318. DOI: 10.2429/proc.2012.6(1)043.

[38] Baran W, Adamek E, Ziemiańska J, Makowski A, Sobczak A. Assessment of susceptibility of sulfonamides drugs to biodegradation in environmental samples. Proc ECOpole. 2013;7:13-21. DOI: 10.2429/proc.2013.7(1)001.

[39] Adamek E, Baran W, Ziemiańska J, Makowski A, Sobczak A. Use of $\mathrm{TiO}_{2} / \mathrm{FeCl}_{3}$ mixture in environmental cleaning technology. Proc ECOpole. 2012;6:451-457. DOI: 10.2429/proc.2012.6(2)059. 
[40] Baran W, Zawora D, Adamek E, Makowski A, Sobczak A. Usuwanie sulfonamidów ze ścieków metodą elektrokoagulacji (Removal of sulfonamides from wastewater by electrocolagulation). Proc ECOpole. 2011;5:479-485. http://tchie.uni.opole.pl/PECO11_2/PECO_2011_2p2.pdf.

[41] Johnson AC, Jurgens MD, Williams RJ, Kummerer K, Kortenkamp A, Sumpter JP. Do cytotoxic chemotherapy drugs discharged into rivers pose a risk to the environment and human health? An overview and UK case study. J Hydrology. 2008;348:167-175. DOI: 10.1016/j.jhydrol.2007.09.054.

[42] Kugathas S, Williams RJ, Sumpter JP. Prediction of environmental concentrations of glucocorticoids: the River Thames, UK, as an example. Environ Int. 2012;40:15-23. DOI: 10.1016/j.envint.2011.11.007.

[43] Rúa-Gómez PC, Püttmann W. Occurrence and removal of lidocaine, tramadol, venlafaxine, and their metabolites in German wastewater treatment plants. Environ Sci Pollut Res. 2012;19:689-699. DOI: 10.1007/s11356-011-0614-1.

[44] Kosonen J, Kronberg L. The occurrence of antihistamines in sewage waters and in recipient rivers. Environ Sci Pollut Res. 2009;16:555-564. DOI: 10.1007/s11356-009-0144-2.

[45] Jain S, Kumar P, Vyas RK, Pandit P, Dalai AK. Occurrence and removal of antiviral drugs in environment: A review. Water Air Soil Pollut. 2013;224:1410-44. DOI: 10.1007/s11270-012-1410-3.

[46] Zwiener C, Frimmel FH. Short-term test with a pilot sewage plant and biofilm reactors for the biological degradation of the pharmaceuticals compounds clofibric acid, ibuprofen and diclofenac. Sci Total Environ. 2003;309:201-211. DOI: 10.1016/S0048-9697(03)00002-0.

[47] Migowska N, Caban M, Stepnowski P, Kumirska J. Simultaneous analysis of non-steroidal anti-inflammatory drugs and estrogenic hormones in water and wastewater samples using gas chromatography-mass spectrometry and gas chromatography with electron capture detection. Sci Total Environ. 2012;441:77-88. DOI: 10.1016/j.scitotenv.2012.09.043.

[48] Baranowska I, Kowalski B. A rapid UHPLC method for the simultaneous determination of drugs from different therapeutic groups in surface water and wastewater. Bull Environ Contam Toxicol. 2012;89:8-14. DOI: 10.1007/s00128-012-0634-7.

[49] Kotowska U, Kapelewska J, Sturgulewska J. Determination of phenols and pharmaceuticals in municipal wastewaters from Polish treatment plants by ultrasound-assisted emulsification-roextraction followed by GC-MS. Environ Sci Pollut Res. 2014;21:660-673. DOI: 10.1007/s11356-013-1904-6.

[50] Baker DR, Kasprzyk-Hordern B. Spatial and temporal occurrence of pharmaceuticals and illicit drugs in the aqueous environment and during wastewater treatment: new developments. Sci Total Environ. 2013;454-455:442-456. DOI: 10.1016/j.scitotenv.2013.03.043.

[51] Al-Rifai JH, Gabelish CL. Occurrence of pharmaceutically active and non-steroidal estrogenic compounds in three different wastewater recycling schemes in Australia. Chemosphere. 2007;69:803-815. DOI: 10.1016/j.chemosphere.2007.04.069.

[52] Pedrouzo M, Borrull F, Pocurull E, Marcé RM. Presence of pharmaceuticals and hormones in waters from sewage treatment plants. Water Air Soil Pollut. 2011;217:267-281. DOI: 10.1007/s11270-010-0585-8.

[53] Valcárcel Y, González Alonso S, Rodríguez-Gil JL, Romo Maroto R, Gil A, Catalá M. Analysis of the presence of cardiovascular and analgesic/anti-inflammatory/antipyretic pharmaceuticals in river- and drinking-water of the Madrid Region in Spain. Chemosphere. 2011;82:1062-1071. DOI: 10.1016/j.chemosphere.2010.10.041.

[54] Zuccato E, Castiglioni S, Fanelli R, Reitano G, Bagnati R, Chiabrando Ch. Pharmaceuticals in the environment in Italy: Causes, occurrence, effects and control. Environ Sci Pollut Res. 2006;13:15-21. DOI: 10.1065/espr2006.01.004.

[55] Daneshvar A, Svanfelt J, Kronberg L, Weyhenmeyer GA. Winter accumulation of acidic pharmaceuticals in a Swedish river. Environ Sci Pollut Res. 2010;17:908-916. DOI: 10.1007/s11356-009-0261-y.

[56] Kasprzyk-Hordern B, Dąbrowska A, Vieno N, Kronberg L, Nawrocki J. Occurrence of acidic pharmaceutical in the Warta River in Poland. Chem Anal. 2007;52:289-303.

[57] Zhou LJ, Ying GG, Zhao JL, Yang JF, Wang L, Yang B. Trends in the occurrence of human and veterinary antibiotics in the sediments of the Yellow River, Hai River and Liao River in northern China. Environ Pollut. 2011;159:1877-1885. DOI: 10.1016/j.envpol.2011.03.034.

[58] Tamtam F, Mercier F, Le Bot B, Eurin J. Occurrence and fate of antibiotics in the Seine River in various hydrological conditions. Sci Total Environ. 2008;393:84-95. DOI: 10.1016/j.scitotenv.2007.12.009.

[59] Morteani G, Moller P, Fuganti A, Paces T. Input and fate of anthropogenic estrogens and gadolinium in surface water and sewage plants in the hydrological basin of Prague (Czech Republic). Environ Geochem Health. 2006;28:257-264. DOI: 10.1007/s10653-006-9040-6.

[60] Wang L, Ying GG, Zhao JL, Yang XB. Occurrence and risk assessment of acidic pharmaceuticals in the Yellow River, Hai River and Liao River of north China. Sci Total Environ. 2010;408: 3139-3147. DOI: 10.1016/j.scitotenv.2010.04.047. 
[61] Loos R, Wollgast J, Huber T, Hanke G. Polar herbicides, pharmaceutical products, perfluorooctanesulfonate (PFOS), perfluorooctanoate (PFOA), and nonylphenol and its carboxylates and ethoxylates in surface and tap waters around Lake Maggiore in Northern Italy. Anal Bioanal Chem. 2007;387:1469-1478. DOI: 10.1007/s00216- 006-1036-7.

[62] Zheng Q, Zhang R, Wang Y, Pan X. Occurrence and distribution of antibiotics in the Beibu Gulf, China: impacts of river discharge and aquaculture activities. Mar Environ Res. 2012;78:26-33. DOI: 10.1016/j.marenvres.2012.03.007.

[63] Szymonik A, Lach J. Pharmaceuticals - potential threads to water environment. Eng Protect Environ. 2012;15:249-265.

[64] Valcárcel Y, Martínez F, González-Alonso S, Segura Y, Catalá M. Drugs of abuse in surface and tap waters of the Tagus River basin: heterogeneous photo-Fenton process is effective in their degradation. Environ Int. 2012;41:35-43. DOI:10.1016/j.envint.2011.12.006.

[65] Stasinakis AS, Mermigka S, Samaras VG, Farmaki E. Occurrence of endocrine disrupters and selected pharmaceuticals in Aisonas River (Greece) and environmental risk assessment using hazard indexes. Environ Sci Pollut Res. 2012;19:1574-1583. DOI: 10.1007/s11356-011-0661-7.

[66] Helenkar A, Sebok A, Zaray G, Molnar-Perl I, Vasanits-Zsigrai A. The role of the acquisition methods in the analysis of the non-steroidal anti-inflammatory drugs in Danube River by gas chromatography-mass spectrometry. Talanta. 2010;82:600-607. DOI: 10.1016/j.talanta.2010.05.014.

[67] Vystavna Y, Huneau F, Grynenko V, Vergeles Y. Pharmaceuticals in rivers of two regions with contrasted socio-economic conditions: Occurrence, accumulation, and comparison for Ukraine and France. Water Air Soil Pollut. 2012;223:2111-2124. DOI: 10.1007/s11270-011-1008-1.

[68] Kosjek T, Heath E, Krbavcic A. Determination of non-steroidal anti-inflammatory drug (NSAIDs) residues in water samples. Environ Int. 2005;31:679-685. DOI: 10.1016/j.envint.2004.12.001.

[69] Robinson I, Junqua G, Van Coillie R, Thomas O. Trends in the detection of pharmaceutical products, and their impact and mitigation in water and wastewater in North America. Anal Bioanal Chem. 2007;387:1143-1151. DOI: 10.1007/s00216-006-0951-y.

[70] Packer JL, Werner JJ, Latch DE, McNeill K. Photochemical fate of pharmaceuticals in the environment: Naproxen, diclofenac, clofibric acid, and ibuprofen. Aquat Sci. 2003;65:342-351. DOI: 10.1007/s00027-003-0671- 8 .

[71] Writer JH, Ferrer I, Barber LB, Thurman EM. Widespread occurrence of neuro-active pharmaceuticals and metabolites in 24 Minnesota rivers and wastewaters. Sci Total Environ. 2013;461-462:519-527. DOI: 10.1016/j.scitotenv.2013.04.099.

[72] Gros M, Petrovic M, Ginebreda A, Barcelo D. Sources, Occurrence, and Environmental Risk Assessment of Pharmaceuticals in the Ebro River Basin. In: Barcelo D, Petrovic M, editors. The Handbook of Environmental Chemistry. Berlin Heidelberg: Springer; 2011. DOI: 10.1007/698_2010_72.

[73] Bound JP, Voulvoulis N. Predicted and measured concentrations for selected pharmaceuticals in UK rivers: implications for risk assessment. Water Res. 2006;40:2885-2892. DOI: 10.1016/j.watres.2006.05.036.

[74] Murata A, Takada H, Mutoh K, Hosoda H. Nationwide monitoring of selected antibiotics: Distribution and sources of sulfonamides, trimethoprim, and macrolides in Japanese rivers. Sci Total Environ. 2011;409:5305-5312. DOI: 10.1016/j.scitotenv.2011.09.014.

[75] Vulliet E, Cren-Olivé C. Screening of pharmaceuticals and hormones at the regional scale, in surface and groundwaters intended to human consumption. Environ Pollut. 2011;159:2929-2934. DOI: 10.1016/j.envpol.2011.04.033.

[76] Shala L, Foster GD. Surface water concentrations and loading budgets of pharmaceuticals and other domestic-use chemicals in an urban watershed (Washington, DC, USA). Arch Environ Contam Toxicol. 2010;58:551-561. DOI: 10.1007/s00244-009-9463-z

[77] Zhou XF, Dai CM, Zhang YL. A preliminary study on the occurrence and behavior of carbamazepine (CBZ) in aquatic environment of Yangtze River Delta, China. Environ Monit Assess. 2011;173:45-53. DOI: 10.1007/s10661-010-1369-8.

[78] Moldovan Z, Chira R, Alder AC. Environmental exposure of pharmaceuticals and musk fragrances in the Somes River before and after upgrading the municipal wastewater treatment plant Cluj-Napoca, Romania. Environ Sci Pollut Res. 2009;16:46-54. DOI: 10.1007/s11356-008-0047-7.

[79] Madureira VT, Barreiro JC, Rocha MJ, Rocha E. Spatiotemporal distribution of pharmaceuticals in the Douro River estuary (Portugal). Sci Total Environ. 2010;408:5513-5520. DOI: 10.1016/j.scitotenv.2010.07.069.

[80] Koreje KO, Demeestere K, De Wispelaere P, Vergeynst L. From multi-residue screening to target analysis of pharmaceuticals in water: development of a new approach based on magnetic sector mass spectrometry and application in the Nairobi River basin, Kenya. Sci Total Environ. 2012;437:153-164. DOI: 10.1016/j.scitotenv.2012.07.052. 
[81] Nödler K, Licha T, Fischer S, Wagner B. A case study on the correlation of micro-contaminants and potassium in the Leine River (Germany). Appl Geochem. 2011;26:2172-2180. DOI: 10.1016/j.apgeochem.2011.08.001.

[82] Locatelli MA, Sodre' F, Jardim WF. Determination of antibiotics in Brazilian surface waters using liquid chromatography-electrospray tandem mass spectrometry. Arch Environ Contam Toxicol. 2011;60:385-393. DOI: $10.1007 / \mathrm{s} 00244-010-9550-1$.

[83] Daneshvar A, Svanfelt J, Kronberg L. Seasonal variations in the occurrence and fate of basic and neutral pharmaceuticals in a Swedish river-lake system. Chemosphere. 2010;80:301-309. DOI: 10.1016/j.chemosphere.2010.03.060.

[84] Schmitt-Jansen M, Bartels P, Adler N, Altenburger R. Phytotoxicity assessment of diclofenac and its phototransformation products. Anal Bioanal Chem. 2007;387:1389-1396. DOI: 10.1007/s00216-006-0825-3.

[85] Zuccato E, Chiabrando Ch, Castiglioni S, Calamari D, Bagnati R. Cocaine in surface waters: a new evidence-based tool to monitor community drug abuse. Environ Health: A Global Access Sci Source. 2005;4:14-21. DOI: 10.1186/1476-069X-4-14.

[86] Próba M. Chosen anthropogenic factors of surface water pollution analysis of the phenomen. Eng Protect Environ. 2013;16:113-124. http://yadda.icm.edu.pl/baztech/element/bwmeta1.element.baztech-e4678fb59f9e-4f9c-88ac-5fbeb0839254.

[87] Vazquez-Roig P, Andreu V, Blasco C, Picó Y. SPE and LC-MS/MS determination of 14 illicit drugs in surface waters from the Natural Park of L'Albufera (València, Spain). Anal Bioanal Chem. 2010;397:2851-2864. DOI: 10.1007/s00216-010-3720-x.

[88] Binelli A, Pedriali A, Riva C, Parolini M. Illicit drugs as new environmental pollutants: cyto-genotoxic effects of cocaine on the biological model Dreissena polymorpha. Chemosphere. 2012;86:906-911. DOI: 10.1016/j.chemosphere.2011.10.056.

[89] Berset JD, Brenneisen R, Mathieu Ch. Analysis of llicit and illicit drugs in waste, surface and lake water samples using large volume direct injection high performance liquid chromatography - electrospray tandem mass spectrometry (HPLC-MS/MS). Chemosphere. 2010;81:859-866. DOI: 10.1016/j.chemosphere.2010.08.011.

[90] Pal R, Megharaj M, Kirkbride KP, Naidu R. Illicit drugs and the environment - a review. Sci Total Environ. 2013;463-464:1079-1092. DOI: 10.1016/j.scitotenv.2012.05.086

[91] Nuijs AL, Covaci A. The Removal of Illicit Drugs and Metabolites During Wastewater and Drinking Water Treatment. In: Sharma SK, Sanhgi R, editors. Advances in Water Treatment and Pollution Prevention. Dordrecht Netherlands: Springer; 2012. DOI: 10.1007/978-94-007-4204-8 3.

[92] Postigo C, López de Alda MJ, Barceló D. Drugs of abuse and their metabolites in the Ebro River basin: occurrence in sewage and surface water, sewage treatment plants removal efficiency, and collective drug usage estimation. Environ Int. 2010;36:75-84. DOI: 10.1016/j.envint.2009.10.004.

[93] Boles TH, Wells M. Analysis of amphetamine and methamphetamine as emerging pollutants in wastewater and wastewater-impacted streams. J Chromatography A. 2010;1217:2561-2568. DOI: 10.1016/j.chroma.2010.01.014.

[94] Boleda RM, Huerta-Fontela M, Ventura F, Galceran T. Evaluation of the presence of drugs of abuse in tap waters. Chemosphere. 2011;84:1601-1607. DOI: 10.1016/j.chemosphere.2011.05.033.

[95] Fent K. Effects of Pharmaceuticals on Aquatic Organisms. In: Kümmerer K. editor. Pharmaceuticals in Environment. Berlin Heidelberg: Springer; 2008. DOI: 10.1007/978-3-540-74664-5_12.

[96] Groning J, Held C, Garten C, Claußnitzer U. Transformation of diclofenac by the indigenous microflora of river sediments and identification of a major intermediate. Chemosphere. 2007;69:509-516. DOI: 10.1016/j.chemosphere.2007.03.037.

[97] Grenni P, Patrolecco L, Ademollo N, Tolomei A. Degradation of Gemfibrozil and Naproxen in a river water ecosystem. Microchemical J. 2012;107:158-164. DOI: 10.1016/j.microc.2012.06.008.

[98] Hartwig Ch, Muth-Köhne E, Düring R-A. Screening for ecotoxicological effects of antiepileptic drugs in biologically treated waste water originating from an epilepsy ward by Danio rerio embryos. Environ Sci Europe. 2013;25:29-41. DOI: 10.1186/2190-4715-25-29.

[99] Nentwig G. Effects of pharmaceuticals on aquatic invertebrates. Part II: The antidepressant drug fluoxetine. Arch Environ Contam Toxicol. 2007;52:163-170. DOI: 10.1007/s00244-005-7190-7.

[100] Barry MJ. Effects of fluoxetine on the swimming and behavioural responses of the Arabian killifish. Ecotoxicology. 2013;22:425-432. DOI: 10.1007/s10646-012-1036-7.

[101] Di Poi C, Evariste L, Serpentini A, Halm-Lemeille MP. Toxicity of five antidepressant drugs on embryo- larval development and metamorphosis success in the Pacific oyster, Crassostrea gigas. Environ Sci Pollut Res. 2014;21:13302-13314. DOI: 10.1007/s11356-013-2211-y. 
[102] Backhaus T, Sumpter J, Blanck H. On the Ecotoxicology of Pharmaceutical Mixtures. In: Kümmerer K, editor. Pharmaceuticals in Environment. Berlin Heidelberg: Springer; 2008. DOI: 10.1007/978-3-540-74664-5_16.

[103] Baran W, Adamek E, Makowski A, Sobczak A. Assesment of sulfonamides occurrence in the biosphere. Ecol Chem Eng. A. 2012;19:1153-1171. DOI: 10.2428/ecea.2012.19(10)110.

[104] Woutersen M, Belkin S, Brouwer B, van Wezel AP. Are luminescent bacteria suitable for online detection and monitoring of toxic compounds in drinking water and its sources? Anal Bioanal Chem. 2011;400:915- 929. DOI: 10.1007/s00216-010-4372-6.

[105] Touraud E, Roig B, Sumpter JP, Coetsier C. Drug residues and endocrine disruptors in drinking water: risk for humans? Int. J Hyg Environ Health. 2011;214:437-441. DOI: 10.1016/j.ijheh.2011.06.003.

[106] Bull RJ, Crook J, Whittaker M, Cotruvo JA. Therapeutic dose as the point of departure in assessing potential health hazards from drugs in drinking water and recycled municipal wastewater. Regul Toxicol Pharmacol. 2011;60:1-19. DOI: 10.1016/j.yrtph.2009.12.010.

[107] Zgoła-Grzeskowiak A. Application of DLLME to isolation and concentration of non-steroidal anti-inflammatory drugs in environmental water samples. Chromatographia. 2010;72:671-678. DOI: 10.1365/s10337-010-1702-y.

[108] Vulliet E, Cren-Olive' C, Grenier-Loustalot M-F. Occurrence of pharmaceuticals and hormones in drinking water treated from surface waters. Environ Chem Lett. 2011;9:103-114. DOI: 10.1007/s10311-009-0253-7.

[109] Webb S, Ternes T, Gibert M, Olejniczak K. Indirect human exposure to pharmaceuticals via drinking water. Toxicol Lett. 2003;142:157-167. DOI: 10.1016/S0378-4274(03)00071-7.

[110] Kleywegt S, Pileggi V, Yang P, Hao Ch. Pharmaceuticals, hormones and bisphenol A in untreated source and finished drinking water in Ontario, Canada - Occurrence and treatment efficiency. Sci Total Environ. 2011:409:1481-1488. DOI: 10.1016/j.scitotenv.2011.01.010.

[111] Kumar A, Xagoraraki I. Human health risk assessment of pharmaceuticals in water: an uncertainty analysis for meprobamate, carbamazepine, and phenytoin. Regul Toxicol Pharmacol. 2010;57:146-156. DOI: 10.1016/j.yrtph.2010.02.002.

[112] Maggioni S, Balaguer P, Chiozzotto C, Benfenati E. Screening of endocrine-disrupting phenols, herbicides, steroid estrogens, and estrogenicity in drinking water from the waterworks of 35 Italian cities and from PET- bottled mineral water. Environ Sci Pollut Res. 2013;20:1649-1660. DOI: 10.1007/s11356-012-1075-x.

[113] Green Brody J, Aschengrau A, McKelvey W, Swartz Ch. Breast cancer risk and drinking water contaminated by wastewater: a case control study. Environ Health. 2006;5:28-39. DOI: $10.1186 / 1476-069 X-5-28$.

[114] Aschengrau A, Weinberg JM, Janulewicz PA, Romano ME. Affinity for risky behaviors following prenatal and early childhood exposure to tetrachloroethylene (PCE)-contaminated drinking water: a retrospective cohort study. Environ Health. 2011;10:102-115. DOI: 10.1186/1476-069X-10-102.

[115] Zwiener C. Occurrence and analysis of pharmaceuticals and their transformation products in drinking water treatment. Anal Bioanal Chem. 2007;387:1159-1162. DOI: 10.1007/s00216-006-0818-2.

[116] COM 875 report from Commission of European Parliament and the Council on the outcome of the review of Annex of Directive 2000/60/EC of the European Parliament and of the Council on priority substances in the field of water policy. Brussels: 31.01.2012;2011. https://ec.europa.eu/transparency/regdoc/rep/ 1/2011/EN/1-2011-875-EN-F1-1.Pdf. 